\title{
Profile of fatty acids, vitamins, phytosterols and phenolic acids in Trachystemon orientalis plant and evaluation of its antioxidant activity
}

\author{
Ersin Demir ${ }^{*}$ \\ 1*Duzce University, Faculty of Agriculture, Departmant of Agricultural Biotechnology, Duzce, Turkey, (ORCID: 0000-0002-7676-5953), ersncan.dmr@gmail.com
}

(First received 22 November 2021 and in final form 5 January 2022)

(DOI: $10.31590 /$ josat.1027061)

ATIF/REFERENCE: Demir, E. (2022). Profile of fatty acids, vitamins, phytosterols and phenolic acids in Trachystemon orientalis plant and evaluation of its antioxidant activity. European Journal of Science and Technology, (33), 112-118.

\begin{abstract}
The present study focuses on the phytochemical content and antiradical properties of Trachystemon orientalis L., which grown spontaneously and consumed as food in rural areas of Düzce (from Turkey) province. DPPH, ABTS and OH radical scavenging tests were carried for identifying the antiradical properties of the extracts of this plant. In addition, the metal chelating potential of this plant was also evaluated. The antioxidant activity was considered and interpreted based on the level of the \% inhibition value. The average ABTS radical cleaning activities of T. orientalis extracts of methanol, ethanol and pure water were found to be $93.35 \%$, $91.32 \%, 94.70 \%$, respectively. The average DPPH radical cleaning activites of this plant extracts of methanol, ethanol and pure water were determined as $37.26 \%, 7.95 \%, 52.26 \%$, respectively. T. orientalis the $\mathrm{OH}$ radical cleaning test results of the extracts of plant prepared from methanol, ethanol and pure water were determined as $60.85 \%, 61.33 \%, 24.12 \%$, respectively. In addition, the metal chelation test results of methanol, ethanol and pure water extracts of this plant were found to be $63.57 \%, 42.04 \%, 82.64 \%$. It was determined that the highest content of protein $(20.93 \mathrm{mg} \mathrm{BSA} / \mathrm{g})$, proanthocyanidin $(13.76 \mathrm{mg} \mathrm{CE} / \mathrm{g})$ and phenolic $(3621.03 \mu \mathrm{g}$ $\mathrm{GAE} / \mathrm{g})$ was found in pure water extract of $T$. orientalis. It has been determined that gallic acid $(187.67 \mu \mathrm{g} / \mathrm{g})$, vanillic acid $(3.78$ $\mu \mathrm{g} / \mathrm{g})$, rosmarinic acid $(10.55 \mu \mathrm{g} / \mathrm{g})$ and hydrocynamic acid $(0.78 \mu \mathrm{g} / \mathrm{g})$ are found in different proportions in T. orientalis plant. It has been observed that $T$. orientalis is an important source of palmitic acid, stearic acid, oleic acid, linoleic acid, $\gamma$-linolenic acid, alphalinolenic acid, gadoleic acid and docosahexaenoic acid. It has been established that this plant has a low content of fat-soluble vitamins and phytosterols.
\end{abstract}

Keywords: Edible plants, antioxidant, fatty acid composition, vitamins, phenolic acids, phytosterols

\section{Trachystemon orientalis bitkisinin yăg asidi, vitamin, fitosterol ve fenolik asit profili ve antioksidan aktivitesinin değerlendirilmesi}

$\ddot{O} \mathbf{z}$

Bu çalışmada Düzce ilinin kırsal yerlerinde kendiliğinden yetişen ve gıda olarak tüketilen Trachystemon orientalis L.'nin fitokimyasal içeriği ile antiradikal özellikleri araştırılmıştır. Bu bitkinin özütlerinin antiradikal özellikleri DPPH, ABTS ve OH radikal temizleme testleri kullanılarak belirlendi. Ayrıca bu bitkinin metal şelatlama potansiyeli de değerlendirildi. Antioksidan aktivite, \% inhibisyon değerinin seviyesi esas alınarak değerlendirilmiş ve yorumlanmıştır. T. orientalis in metanol, etanol ve saf su özütlerinin ortalama ABTS radikal temizleme aktiviteleri sırasıyla \%93.35, \%91.32, \%94.70 olarak tespit edilmiştir. Bu bitkinin farklı konsantrasyonlarda metanol, etanol ve saf su özütlerinin ortalama DPPH radikal temizleme aktiviteleri sırasıly \%37.26, \%7.95, \%52.26 olarak belirlenmiştir. T. orientalis bitkisinin metanol, etanol ve saf suda hazırlanan özütlerinin $\mathrm{OH}$ radikal temizleme test sonuçları sırasıyla $\% 60.85$, \%61.33, \%24.12 olarak tespit edilmiştir. Ayrıca bu bitkinin metanol, etanol ve saf suda hazırlanan özütlerinin metal şelatlama test sonuçları \% 63.57, \%42.04, \%82.64 olarak saptanmıştır. En yüksek protein (20.93 mg BSA/g), proantosiyanidin (13.76 $\mathrm{mg} \mathrm{CE} / \mathrm{g})$ ve fenolik (3621.03 $\mu \mathrm{g} \mathrm{GAE} / \mathrm{g})$ içeriği T. orientalis bitkisinin saf su özütünde belirlenmiştir. T. orientalis bitkisinde gallik asit $(187.67 \mu \mathrm{g} / \mathrm{g})$, vanillik asit $(3.78 \mu \mathrm{g} / \mathrm{g})$, rosmarinik asit $(10.55 \mu \mathrm{g} / \mathrm{g})$ ve hidrosinamik asidin $(0.78 \mu \mathrm{g} / \mathrm{g})$ farkl1 oranlarda bulunduğu belirlenmiştir. T.orientalis bitkisinin palmitic acid, stearic acid, oleic acid, linoleic acid, $\gamma$-linolenic acid, alpha-linolenic acid, gadoleic acid ve docosahexaenoic acid bakımından önemli bir kaynak olduğu görülmüştür. Bu bitkinin yağda çözünebilen vitamin ve fitosterol içeriğinin düşük olduğu saptanmıştır.

Anahtar Kelimeler: Yenilebilir bitkiler, antioksidan, yăg asidi bileşimi, vitaminler, fenolik asitler, fitosteroller

* Corresponding Author: ersncan.dmr@gmail.com 


\section{Introduction}

Fruit and vegetable-based diets are widely recommended due to their health-promoting properties. Fruits and vegetables have always found a place in dietary guidelines since ancient times due to the high content of vitamins (A, E and C) that they have. Today, it has been revealed that fruits and vegetables have many phytochemicals that have significant potential on human health. One of the most remarkable properties of these phytochemicals is their high antioxidant potential (Slavin and Lloyd, 2012).

Edible plants or compounds of plant origin can be utilized medicinally as preventive and/or therapeutic measures against various ailments. A number of studies attribute the beneficial effects of dietary herbs on health to the presence of biologically active components showing strong antioxidant activity. It has been shown by extensive studies that plant extracts or their components have the ability to remove free radicals and prevent lipid peroxidation (Woo et al., 2017). Imbalance between the generation and buildup of reactive oxygen species (ROS) in cells and tissues, and the biological system's ability to detoxify these reactive products, causes an oxidative stress.Oxidative stress caused by ROS leads to disturbances in redox homeostasis (Pizzino et al., 2017). ROS is also produced during metabolic processes as intracellular endogenous as well as environmental stress conditions which UV radiation, pollutants, heavy metals and xenobiotics, such as can be produced by exogenous stimuli (Woo et al., 2017). Oxidative stress might negatively impact on the, cell membranes, lipids, proteins, lipoproteins, and deoxyribonucleic acid (DNA) cellular architecture. Oxidative stress also affects a large number of cellular processes, including the core signaling pathways associated with the development of systematic and/or chronic disorders (Bhattacharyya et al., 2014; Hussain et al., 2016;).

As a result, removing cellular oxidants and restoring the redox balance is critical. Cells use endogenous and exogenous antioxidant defense systems to protect themselves from cellular damage caused by ROS (Sharifi-Rad et al., 2020). Herbaceous plants that grow spontaneously in nature and they have an important place in human nutrition. Especially after it was understood that edible wild plants can have positive effects on human health; great attention was given to the study of the nutritional content and pharmacological properties of these plants. The researchers drew attention to the fact that these plants are important sources in terms of fatty acids, phytosterols, protein, vitamins, minerals, antioxidants, secondary metabolites and phenolic compounds (Özbakır Özer and Aksoy, 2019). It seems the plants growing spontaneously are preferred by the public both during the seasons when vegetable varieties are in decline, and because of their medicinal and economic properties. These plants are collected by people living in rural areas and consumed both as food and earn income by selling them in bazaars. Many wild plants are consumed intensively as food in Turkey (Özbakır Özer and Aksoy, 2019).

The Black Sea region of Turkey is attracts attention with its natural beauty and amazing biological diversity. It seems that there is a lot of self-growing and edible plant diversity in this region. One of these plants is Trachystemon orientalis (Boraginaceae), which is called "galdirik or kaldirik" by the local people. It seems that this plant is intensively consumed by the people of the region in the spring.

e-ISSN: 2148-2683
The objective of the present study was to identify the fatty acid composition, phytosterol, fat-soluble vitamins (A, D, E, K) and phenolic acid content of the $T$. orientalis plant, which is consumed in abundance in Düzce, located in the Western Black Sea region of Turkey. In addition, the antioxidant potential is also investigated for this plant.

\section{Material and Method}

\subsection{Extraction procedures}

T. orientalis was purchased from bazaar in Düzce in the spring. After the plants were washed with water, they were dried in a cool place. Then it was ground into powder in a mechanical grinder. Then, $1 \mathrm{~g}$ of powder sample was extracted in $10 \mathrm{ml}$ of solvent (methanol, ethanol and pure water). The extraction process of all samples took two hours. Then the samples were centrifuged at $5,000 \mathrm{rpm}$ at $+4^{\circ} \mathrm{C}$. Thus, the supernatant was obtained to be used in the studies (such as ABTS (2,2'-Azinobis(3-ethylbenzthiazoline-6-sulfonic acid)), hydroxyl, DPPH (2,2-Diphenyl-1-picrylhydrazyl), metal ion chelation and phenolic acids) (Keser et al., 2014).

The powdered samples of the $T$. orientalis plant were homogenized in a mixture of $3 / 2(\mathrm{v} / \mathrm{v})$ hexane isopropyl alcohol for analysis of fatty acid, fat-soluble vitamins and phytosterols (Hara and Radin, 1978). Then the samples were centrifuged at $5,000 \mathrm{rpm}$ at $+4^{\circ} \mathrm{C}$. The supernatant portion was used in the analyses.

\subsection{Determination of antiradical activities}

The radical scavenging activities (RSAs) of $\mathrm{ABTS}^{\cdot+}$, hydroxyl, DPPH, and metal ions were measured using the methods of Re et al. (1999); Halliwell et al. (1987); BrandWilliams et al. (1995); and Decker et al. (1990), respectively. All tests were repeated thrice and the average values were computed. The radical scavenging activity percentages (RSA \%) for each sample was calculated by the following equation:

$$
\operatorname{RSA} \%=\left[\left(\mathrm{A}_{0}-\mathrm{A}_{1}\right) / \mathrm{A}_{0}\right] \times 100
$$

$\mathrm{A}_{0}$ : control absorbance; $\mathrm{A}_{1}$ : sample absorbance.

\subsection{Phytochemical compounds}

\subsubsection{Total phenolic contents (TPC)}

TPC was determined using the method outlined by Slinkard and Singleton (1977).The gallic acid (GAE) was used as a standard.

\subsubsection{Total proanthocyanidin content (TP)}

PC was calculated according to the approach published by Amaeze et al., (2011). The catechin (CE) was used as a standard.

\subsubsection{Total protein content (TPR)}

The determination of the TPC was carried out based on the method put forth by Lowry et al., (1951). The bovine serum albumin (BSA) was used as a standard.

\subsubsection{Analyses of phenolic acids}

The phenolic acids were determined using HPLC (High performance liquid chromatography) in the $T$. orientalis according to the method given by $\mathrm{Zu}$ et al., (2006). HPLC was 
used to measure gallic acid, vanillic acid, rosmarinic acid, and hydrocinnamic acid in the $T$. orientalis extract.

\subsubsection{Analysis of fatty acids}

Fatty acids in the $T$. orientalis extract were analyzed by $G C$ (Gas chromatography) according to the described method by Christie (1990 and 1992). The fatty acids analysis results were expressed as a percent of samples.

\subsubsection{Analyses of lipophylic vitamins and phytosterols}

HPLC was used to extract lipophilic vitamins and phytosterols from $T$. orientalis, following the methods of Sanchez-Machado et al. (2002) and López-Cervantes et al. (2006). The analyses' results were represented as $\mu \mathrm{g} / \mathrm{g}$.

\subsection{Statistical analyses}

For statistical analysis, SPSS Statistics 18.0 was employed. The analysis of variance (ANOVA) and Duncan's multiple range test (DMRT) were used to examine the antiradical outcomes.

Table $1 . \mathrm{ABTS}^{+\bullet}$ and $\mathrm{DPPH}^{\bullet}$ radicals scavenging activities of Trachystemon orientalis extracts

\begin{tabular}{|c|c|c|}
\hline Concentration $25 \mathrm{mg} / \mathrm{ml}$ & $\begin{array}{c}\text { DPPH' scavenging }^{\circ}(\%) \\
\end{array}$ & $\begin{array}{c}\text { ABTS }^{+\bullet} \\
\text { scavenging }(\%)\end{array}$ \\
\hline T. orientalis (Methanol) & $14.07 \pm 2.88^{\mathrm{b}}$ & $88.52 \pm 5.35^{\mathrm{b}}$ \\
\hline T. orientalis (Ethanol) & $10.96 \pm 0.18^{b}$ & $72.38 \pm 0.48^{\mathrm{c}}$ \\
\hline T. orientalis (Pure water) & $37.64 \pm 4.36^{\mathrm{a}}$ & $97.51 \pm 0.16^{\mathrm{a}}$ \\
\hline \multicolumn{3}{|l|}{ Concentration $50 \mathrm{mg} / \mathrm{ml}$} \\
\hline T. orientalis (Methanol) & $11.89 \pm 0.47^{\mathrm{b}}$ & $98.65 \pm 0.18^{c}$ \\
\hline T. orientalis (Ethanol) & $2.29 \pm 1.53^{\mathrm{c}}$ & $99.43 \pm 0.09^{\mathrm{b}}$ \\
\hline T. orientalis (Pure water) & $47.87 \pm 1.93^{\mathrm{a}}$ & $99.74 \pm 0.09^{\mathrm{a}}$ \\
\hline \multicolumn{3}{|l|}{ Concentration $100 \mathrm{mg} / \mathrm{ml}$} \\
\hline T. orientalis (Methanol) & $19.89 \pm 2.44^{\mathrm{b}}$ & $99.74 \pm 0.09^{\mathrm{a}}$ \\
\hline T. orientalis (Ethanol) & $1.51 \pm 0.74^{\mathrm{c}}$ & $99.63 \pm 0.18^{\mathrm{a}}$ \\
\hline T. orientalis (Pure water) & $62.83 \pm 4.68^{\mathrm{a}}$ & $97.09 \pm 0.70^{\mathrm{b}}$ \\
\hline \multicolumn{3}{|l|}{ Concentration $150 \mathrm{mg} / \mathrm{ml}$} \\
\hline T. orientalis (Methanol) & $37.38 \pm 3.06^{\mathrm{b}}$ & $91.43 \pm 0.82$ \\
\hline T. orientalis (Ethanol) & $2.49 \pm 1.09^{c}$ & $89.98 \pm 2.88$ \\
\hline T. orientalis (Pure water) & $62.41 \pm 4.86^{\mathrm{a}}$ & $92.01 \pm 0.86$ \\
\hline \multicolumn{3}{|l|}{ Concentration $200 \mathrm{mg} / \mathrm{ml}$} \\
\hline T. orientalis (Methanol) & $67.13 \pm 0.86^{\mathrm{a}}$ & $92.01 \pm 0.92$ \\
\hline T. orientalis (Ethanol) & $14.17 \pm 2.97^{\mathrm{b}}$ & $92.89 \pm 0.95$ \\
\hline T. orientalis (Pure water) & $61.32 \pm 4.32^{\mathrm{a}}$ & $93.09 \pm 0.36$ \\
\hline \multicolumn{3}{|l|}{ Concentration $250 \mathrm{mg} / \mathrm{ml}$} \\
\hline T. orientalis (Methanol) & $73.21 \pm 0.87^{\mathrm{a}}$ & $89.77 \pm 0.86^{\mathrm{b}}$ \\
\hline T. orientalis (Ethanol) & $16.30 \pm 3.27^{\mathrm{c}}$ & $93.61 \pm 0.41^{\mathrm{a}}$ \\
\hline T. orientalis (Pure water) & $43.67 \pm 4.43^{\mathrm{b}}$ & $88.78 \pm 0.16^{\mathrm{b}}$ \\
\hline \multicolumn{3}{|l|}{ Average \% } \\
\hline T. orientalis (Methanol) & 37.26 & 93.35 \\
\hline T. orientalis (Ethanol) & 7.95 & 91.32 \\
\hline T. orientalis (Pure water) & 52.62 & 94.70 \\
\hline
\end{tabular}

Different superscript letters within a column are statistically different $(\mathrm{P}<0.05)$

\section{Results and Discussion}

\subsection{Antiradical properties}

The results regarding the antiradical potential of $T$. orientalis extracts are summarized in Table 1 . The higher the calculated \% inhibition value, the higher the antioxidant activity was accepted and the results were evaluated. The average DPPH scavenging activities of the pure water, methanol and ethanol extracts of $T$. orientalis, calculating from various concentrations $(25,50,100$,
150,200 and $250 \mathrm{mg} / \mathrm{ml}$ ), were determined as $52.62,37.26$ and $7.95 \%$, respectively.

According to the ABST radical scavenging activity test of pure water, methanol and ethanol extract of $T$. orientalis, it has been found that the plant has a high radical scavenging property. The average radical scavenging potential of different concentrations $(25,50,100,150,200$ and $250 \mathrm{mg} / \mathrm{ml})$ of this plant was determined as $94.70,93.35$ and $91.32 \%$, for pure water, methanol and ethanol exctracts, respectively (Table 1).

Methanol and ethanol extracts of $T$. orientalis showed high $\mathrm{OH}^{*}$ radical scavenging potential $(60.85$ and $61.33 \%$, respectively) according to the hydroxyl scavenging activity test. However, the hydroxyl scavenging activity of pure water extract was low (24.12\%) (Table 2). 
Table 2. $\mathrm{OH}^{\bullet}$ radicals scavenging activities of Trachystemon orientalis extracts

\section{Concentration $250 \mathrm{mg} / \mathrm{ml}$}

OH` scavenging $(\%)$

T. orientalis (Methanol)

$60.85 \pm 2.20^{\mathrm{a}}$

T. orientalis (Ethanol)

$61.33 \pm 4.09^{\mathrm{a}}$

T. orientalis (Pure water)

Different superscript letters within a column are statistically different $(\mathrm{P}<0.05)$

It was found that the metal chelating activity of low concentrations of methanol and ethanol extracts of $T$. orientalis L. was low $(33.65,30.10 \%$, respectively), but the chelating activity of pure water extract was quite high $(72.81 \%)$. It was found that the metal chelating capacity of these extracts increased with increasing concentration (for methanol 63.57, ethanol 42.04 and pure water $82.64 \%$ ) (Table 3).

Table 3. Metal chelation activity of Trachystemon orientalis extracts

\section{Concentration $75 \mathrm{mg} / \mathrm{ml}$}

Metal chelation activity (\%)

\section{T. orientalis (Methanol)}

$33.65 \pm 1.81^{\mathrm{b}}$

T. orientalis (Ethanol)

$30.10 \pm 3.99^{\mathrm{b}}$

T. orientalis (Pure water)

$72.81 \pm 2.30^{\mathrm{a}}$

\section{Concentration $100 \mathrm{mg} / \mathrm{ml}$}

\section{T. orientalis (Methanol)}

$63.57 \pm 16.29^{\mathrm{a}}$

T. orientalis (Ethanol)

$42.04 \pm 3.41^{\mathrm{b}}$

T. orientalis (Pure water)

$82.64 \pm 2.33^{\mathrm{a}}$

Different superscript letters within a column are statistically different $(\mathrm{P}<0.05)$

In determination of the antioxidant potential of plant extracts, the using more than one method to obtain more accurate results allows us to achieve better results. Because antioxidant molecules can exert their positive effects through mechanisms such as hydrogen atom transfer, electron transfer, and metal chelation, it is critical to study the antioxidant potential of herbal extracts using various methodologies, according to the literature (Ayvaz, 2015). It seems that DPPH, due to its stable radical property, is often used in the study of radical scavenging activities of herbal extracts (Ayvaz, 2015). According to our results, although there are fluctuations in some concentrations, it can be stated that the radical scavenging activity of DPPH increased due to the increasing concentration of $T$. orientalis extracts. It is seen that there is similar potential in previous studies (Ayhan et al., 2019; Sacan, 2018). It is observed that there are significant changes in the DPPH radical scavenging activity of $T$. orientalis extract depending on the solvent. Especially at a low concentration of T. orientalis. it has been reported that aqueous $(25 \mathrm{mg} / \mathrm{ml})$ extract has a very high DPPH radical scavenging potential. It was determined that with increasing concentration, the radical scavenging property of DPPH begins to decrease (Ayvaz, 2015). In our study, it was found that DPPH radical scavenging activity increased with increasing concentration of methyl alcohol extract. In previous studies, it was illustrated that the DPPH radical scavenging potential of the aqueous extract of $T$. orientalis, depending on the concentration, is higher than that of ethyl alcohol (Ayvaz, 2015). This is supported by our findings. The ABTS radical scavenging test is an antiradical activity test different from the DPPH method; it is widely used in assessing the antioxidant activity of both polar and non-polar samples, as well as food and biological samples (Ayvaz, 2015). In the present study, it was determined that the extracts of $T$. orientalis plant prepared using different solvents showed high ABST radical cleaning properties. According to literature reviews, it seems that the information on the ABST radical scavenging activity of this plant is quite insufficient. In a previous study, it was reported that water and ethyl alcohol extracts of the T. orientalis plant have the potential to scavenge ABST radical. In this study, the $\mathrm{ABTS}^{\cdot+}$ scavenging potential of water and ethanol extracts were identified as 1725 and $240 \mathrm{mmol}$ trolox/kg dry weight, respectively (Ayvaz, 2015).

The hydroxyl radical is one of the most dangerous free radicals found in all reactive oxygen species, and it is primarily responsible for cell and tissue destruction. $\mathrm{OH}$ is highly reactive, reacts with biological molecules such as DNA, proteins and lipids and cause chemical modifications on these molecules. Moreover, hydroxyl radical has been reported to be highly associated with physiological conditions such as oxidative damage, mutagenesis, carcinogenesis and aging (Nimse and Pal, 2015). Therefore, it is important to study plants that have a very high degree of $\mathrm{OH}^{*}$ cleaning activity.

In our study, it was found that methanol and ethanol extracts of the $T$. orientalis plant have an activity of cleaning hydroxyl radicals of more than $50 \%$. It has been found that the capacity of pure aqueous extract to remove hydroxyl radical is approximately at the level of $25 \%$. Similarly, in a previous study, it was reported that the ethanol extract of the $T$. orientalis plant has a high hydroxyl radical scavenging property, but the radical scavenging potential of the water extract was low (Ayvaz, 2015). It has been reported that the extracts or compounds showing chelating activity have the property of preventing lipid peroxidation by stabilizing metals such as iron and copper (Sun et al., 2011). In our study, it is seen that $T$. orientalis extracts have metal chelating activity. In particular, it has been found that pure aqueous extract has a high metal chelating property. In previous studies, it was reported that the metal chelating activity of T. orientalis ethanol extract was low (Ayvaz, 2015; Özen, 2010). The difference in the solvent in which the extract is prepared and the geographical region in which the plant grows may affect the results.

\subsection{Phytochemical composition}

Table 4 shows the amount of total phenolic compounds (TPC), total proanthocyanidin (TP) and total protein (TPR) in $T$. orientalis extracts. TPC amounts of $T$. orientalis methanol, ethanol and pure water extracts of were 749.62, 181.70 and $3621.03 \mu \mathrm{g} \mathrm{GAE} / \mathrm{g}$ extract, respectively; TP amounts were 4.41, 
1.75 and $13.76 \mathrm{mg} \mathrm{CE} / \mathrm{g}$, extract respectively; TPR amount was $20.93 \mathrm{mg} \mathrm{BSA} / \mathrm{g}$ extract.

Demir et al. (2020) reported that the total protein amount was $46.13 \mathrm{mg} / \mathrm{g}$ according to Bradford method for T. orientalis samples in Samsun region. In addition, they found that the anthocyanin content was at the level of $15.05 \mathrm{mg} / 100 \mathrm{~g}$. Roe et al. (2013) reported that the protein amounts of some cultivated plants (green beans, spinach, lettuce, white cabbage and arugula) were $21,26,12,12$ and $36 \mathrm{mg} / \mathrm{g}$, respectively. According to these data, we can say that the plant $T$. orientalis $(20.93 \mathrm{mg} / \mathrm{g})$ has high protein content. It has been reported that the protein content of $T$. orientalis samples collected from different localities varies between $15.71 \%$ and $19.96 \%$ (Kibar and Kibar, 2017). It has been determined that the protein content of $T$. orientalis genotypes varies between 14.1-20.3\% (Özbakır Özer and Aksoy, 2019). In a previous study, the total phenolic content of methanolic leaf and stem extracts of $T$. orientalis were determined as $67.01 \mathrm{mg} \mathrm{GAE} / \mathrm{g}$ and $54.04 \mathrm{mg} \mathrm{GAE} / \mathrm{g}$, respectively (Ayhan et al., 2019). The phenolic content of the aqueous extract of $T$. orientalis was reported to be $90 \mathrm{mg} \mathrm{GAE} / \mathrm{g}$ in another investigation (Ayvaz, 2015).In a previous study, it was found that the total phenolic content equivalent to $36 \mu \mathrm{g}$ of pyrocatechol was found in the aqueous infusion extract of the $T$. orientalis. In addition, in this study, it was determined that the anthocyanin level of the $T$. orientalis was equal to $0.35 \mu \mathrm{mol} / \mathrm{g}$ extract (Sacan, 2018).

The phenolic acids contents of $T$. orientalis are summarized in Table 5. The phenolic acids; gallic acid, vanillic acid, rosmarinic acid and hydrocinnamic acid were determined as $187.67,3.7810 .55$ and $0.78, \mu \mathrm{g} / \mathrm{g}$ in $T$. orientalis, respectively. I have not come across any studies in the literature on the content of phenolic acid in T. orientalis. Dimcheva et al. (2019) identified only rutin $(56.46 \mu \mathrm{g} / \mathrm{ml})$ and myricetin $(630.23 \mu \mathrm{g} / \mathrm{ml})$ flavonoids in $T$. orientalis. In addition, gallic acid and vanillic acid were not detected in this study. In the current study, both phenolic acids were detected in the methanol extract of the $T$. orientalis plant (Table 5). It seems that there is no literature on the phenolic acid composition of this plant. Some studies have been conducted on the total amount of phenolic compounds (Ayvaz, 2015; Sacan, 2018; Ayhan et al., 2019). Therefore, important information about the phenolic acid content of this plant was obtained for the first time in this study. In this study, it was reported for the first time that this plant contains phenolic acids such as gallic acid, vanillic acid, rosmarinic acid and hydrocinnamic acid.

Table 4. Total protein, total phenolic, and total proanthocyanidin contents of Trachystemon orientalis extracts

\begin{tabular}{llll}
\hline & $\begin{array}{l}\text { Total } \\
\text { protein } \\
(\mathrm{mg}\end{array}$ & $\begin{array}{l}\text { Total phenolic } \\
(\mu \mathrm{g} \mathrm{GAE} / \mathrm{g})\end{array}$ & $\begin{array}{l}\text { Total } \\
\text { proanthocyanidin } \\
(\mathrm{mg} \mathrm{CE} / \mathrm{g})\end{array}$ \\
& $\mathrm{BSA} / \mathrm{g})$ & & \\
& & & \\
$T$. & - & $749.62 \pm 321.74$ & $4.41 \pm 1.77$ \\
orientalis & & & \\
\hline e-ISSN: $2148-2683$ & &
\end{tabular}

(Methanol)

$T$.

$181.70 \pm 11.39$

$1.75 \pm 0.19$

orientalis

(Ethanol)

$\begin{array}{llll}T . & 20.93 \pm 1.70 & 3621.03 \pm 290.84 & 13.76 \pm 0.56 \\ \text { orientalis } & & \\ \text { (Pure } & & \\ \text { water) } & & \end{array}$

Total proanthocyanidin contents were expressed as mg catechin equivalent/g extract, and total phenolic content were expressed as $\mu \mathrm{g}$ gallic acid equivalent/g extract. Total protein expressed as mg BSA/g extract.

Table 5. Vitamins, phytosterols, fatty acids and phenolic acids content, and composition in Trachystemon orientalis

Vitamin and phytosterols

$(\mu \mathrm{g} / \mathrm{g})$

$\delta$-Tocopherol

$0.02 \pm 0.04$

Vitamin D2

$0.01 \pm 0.01$

$\alpha$-Tocopherol

$0.13 \pm 0.14$

Ergosterol

$0.19 \pm 0.08$

Vitamin K1

$0.01 \pm 0.01$

Sitosterol

$0.62 \pm 0.42$

$\beta$-sitosterol

$1.14 \pm 0.80$

Vitamin K2

Not detected

Retinol

Not detected

Vitamin D1

Not detected

Fatty acids (FA)

Myristic acid (C14:0)

$0.53 \pm 0.05$

Myristoleic acid (C14:1)

Not detected

Palmitic acid (C16:0)

$26.73 \pm 1.65$

Palmitoleic acid (C16:1n7)

$1.73 \pm 0.32$

Margaric acid (C17:0)

$0.31 \pm 0.03$

Stearic acid (C18:0)

$7.76 \pm 0.52$

Oleic acid (C18:1)

$18.17 \pm 5.71$

Linoleic acid (C18:2)

$23.03 \pm 2.24$ 


\begin{tabular}{|c|c|c|c|}
\hline$\gamma$-linolenic acid (C18:3, n-6) & $4.65 \pm 1.74$ & Trichosanoic acid (C23:0) & Not detected \\
\hline Alpha-linolenic acid (C18:3, n-3) & $5.62 \pm 1.52$ & Nervonic acid (C24:1) & Not detected \\
\hline Gadoleic acid (C20:1) & $6.06 \pm 2.08$ & Phenolic acids & $(\mu \mathrm{g} / \mathrm{g})$ \\
\hline Eicosapentaenoic (EPA) acid (C20:5 n-3) & Not detected & Gallic acid & $187.67 \pm 78.46$ \\
\hline Docosapentaenoic acid (C22:5 n-6) & Not detected & Vanillic acid & $3.78 \pm 0.19$ \\
\hline Heptadecanoic acid (C17:1) & $0.43 \pm 0.45$ & Caffeic acid & Not detected \\
\hline Lignoceric acid (C24:0) & Not detected & Ferulic acid & Not detected \\
\hline Docosahexaenoic acid (C22:6) & $5.49 \pm 1.18$ & Rosmarinic acid & $10.55 \pm 4.02$ \\
\hline Behenic acid (C22:0) & Not detected & Hydrocinnamic acid & $0.78 \pm 0.19$ \\
\hline
\end{tabular}

The antioxidant activity of $T$. orientalis plant extracts obtained from various solvents (methanol, ethanol, pure water) was studied using several techniques in this work. According to the results, it was found that the methanol and pure water extracts of $T$. orientalis plant showed higher antioxidant activity than ethanol extract against the DPPH radical. It has been found that the extracts of this plant have high antioxidant properties against the ABTS radical. It has been determined that the metal chelating potential of this plant depends on the concentration and that there is a high metal chelating potential, especially of methanol and pure water extracts. In addition, it was determined that ethanol and methanol extracts of the $T$. orientalis have a high hydroxyl radical cleaning property compared to pure water extract.

It has been determined that the $T$. orientalis plant is an important source of protein, phenolic compounds and proanthocyanidins. Moreover, it is seen that this plant has an important potential in terms of some fatty acids that are important from a nutritional point of view and is a valuable resource. In addition, it has been determined that this plant is a valuable source of some phenolic acids that are important for health. It has been also determined that the potential of this plant is low in terms of the content of fat-soluble vitamins and phytosterols. According to the data, it can be clearly stated that the $T$. orientalis plant has a significant potential in terms of food and health.

\section{Acknowledge}

In this study, important information about the fat-soluble vitamins (A, D, E, K) and phytocyterol content of the $T$. orientalis plant was also obtained for the first time. According to our findings, it was determined that there are different levels of vitamin and phytosterol composition.

\section{Conclusions and Recommendations}

In this study, the first information about the content of phenolic acid, fatty acid, phytosterol and fat-soluble vitamins of the $T$. orientalis plant was reported in this study.

I wish to thank Prof. Dr. Ökkeş Yılmaz for their contributions.

\section{References}

Amaeze OU, Ayoola GA, Sofidiya MO, Adepoju-Bello AA, Adegoke AO, Coker HA. Evaluation of antioxidant activity of Tetracarpidium conophorum (Müll. Arg) Hutch \& Dalziel leaves. Oxid Med Cell Longev. 2011; 2011:976701. doi: 10.1155/2011/976701.

Ayhan BS, Yalçın E, Çavuşoğlu K, Acar A. Antidiabetic potential and multi-biological activities of Trachystemon 
orientalis extracts. J. Food Meas. Charact 2019; 13:28872893.

Ayvaz Col M. Antioxidant activity of Trachystemon orientalis (L.) G. Don (Borage) grown and eaten as food in Ordu, Turkey. Herba Pol. 2015; 61(4): 40-51.

Bhattacharyya A, Chattopadhyay R, Mitra S, Crowe SE. Oxidative stress: an essential factor in the pathogenesis of gastrointestinal mucosal diseases. Physiol Rev. 2014; 94(2):329-54. doi: 10.1152/physrev.00040.2012.

Brand-Williams W, Cuvelier ME, Berset C. Use of a free radical method to evaluate antioxidant activity. LWT 1995; 28: 25 30. doi.org/10.1016/S0023-6438( 95)80008 -5

Christie WW. (1990). Gas chromatography and lipids. (1th ed.). Scotland: The Oily Pres.

Christie WW. Preparation of fatty acid methyl esters. Inform 1992; 3: 1031-1034.

Decker EA, Welch B. Role of ferritin as a lipid oxidation catalyst in muscle food. J. Agric. Food Chem. 1990; 38: 674-677.

Demir E, Turfan N, Özer H, Üstün NŞ, Pekşen A. Nutrient and bioactive substance contents of edible plants grown naturally in Salıpazarı (Samsun). Acta Sci. Pol. Hortorum Cultus 2020, 19(1), 151-160. doi: 10.24326/asphc.2020.1.14.

Dimcheva V, Kaloyanov N, Karsheva M (2019). The polyphenol composition of Cistus incanus L., Trachystemon orientalis L. and Melissa officinalis L. infusions by HPLC-DAD method. Open J Anal Bioanal Chem 3(1): 031-038. DOI: http://dx.doi.org/10.17352/ojabc.000008.

Halliwell B, Gutteridge JM, Aruoma OI. The deoxyribose method: a simple "test-tube" assay for determination of rate constants for reactions of hydroxyl radicals. Anal Biochem. 1987; 165(1):215-9. doi: 10.1016/0003-2697(87)90222-3.

Hara A, Radin NS. Lipid extraction of tissues with a low-toxicity solvent. Anal Biochem. 1978; 90(1):420-6. doi: 10.1016/0003-2697(78)90046-5.

Hussain T, Tan B, Yin Y, Blachier F, Tossou MC, Rahu N. Oxidative stress and inflammation: What polyphenols can do for us? Oxid Med Cell Longev. 2016; 2016:7432797. doi: 10.1155/2016/7432797.

Keser S, Demir E, Yilmaz Ö. Phytochemicals and antioxidant activity of the almond kernel (Prunus dulcis Mill.) from Turkey. J. Chem. Soc. Pak 2014; 36: 534-541.

Kibar B, Kibar H. Determination of the nutritional and seed properties of some wild edible plants consumed as vegetable in the Middle Black Sea Region of Turkey. S. Afr. J. Bot. 2017; 108:117-125.

López-Cervantes J, Sánchez-Machado DI, Ríos-Vázquez NJ. High-performance liquid chromatography method for the simultaneous quantification of retinol, alpha-tocopherol, and cholesterol in shrimp waste hydrolysate. J Chromatogr A. 2006; 1105(1-2):135-9. doi: 10.1016/j.chroma.2005.08.010.

Lowry OH, Rosebrough NJ, Farr AL, Randall RJ. Protein measurement with the Folin phenol reagent. J Biol Chem. 1951; 193(1):265-75.

Nimse SB, Pal D. Free radicals, natural antioxidants, and their reaction mechanisms. RSC Adv., 2015, 5, 27986-28006. doi: 10.1039/c4ra13315c.

Özbakır Özer M, Aksoy M. Mineral composition and nutritional properties of Trachystemon orientalis (L.) G. Don populations in the central black sea region of Turkey. Acta Sci. Pol. Hortorum Cultus, 2019; 18(4):157-167. doi: 10.24326/asphc.2019.4.15.
Özcan T. Analysis of the total oil and fatty acid composition of seeds of some Boraginaceae taxa from Turkey. Plant Syst Evol 2008 274:143-153. doi 10.1007/s00606-008-0039-6

Özen T. Antioxidant activity of wild edible plants in the Black Sea Region of Turkey. Grasas Aceites 2010; 61(1): 86-94.

Özer, M.Ö., Aksoy, M. Mineral composition and nutritional properties of Trachystemon orientalis (L.) G. Don populations in the Central Black Sea Region of Turkey. Acta Sci. Pol. Hortorum Cultus (2019; 18(4): 157-167. doi: 10.24326/asphc.2019.4.15.

Pizzino G, Irrera N, Cucinotta M, Pallio G, Mannino F, Arcoraci V, Squadrito F, Altavilla D, Bitto A. Oxidative Stress: Harms and benefits for human health. Oxid Med Cell Longev. 2017; 2017:8416763. doi: 10.1155/2017/8416763.

Re R, Pellegrini N, Proteggente A, Pannala A, Yang M, RiceEvans C. Antioxidant activity applying an improved ABTS radical cation decolorization assay. Free Radic Biol Med. 1999; 26(9-10):1231-7. doi: 10.1016/s0891-5849(98)003153.

Roe M, Church S, Pinchen H, Finglas P. Nutrient analysis of fruit and vegetables. Analytical Report. Institute of Food Research, Norwich Research Park, Colney, Norwich. 2013.

Sacan O. Antioxidant Activity, Total phenol and total flavonoid contents of Trachystemon orientalis (L.) G. Don. Eur J Biol 2018; 77(2): 70-75.

Sánchez-Machado DI, López-Hernández J, Paseiro-Losada P. High-performance liquid chromatographic determination of alpha-tocopherol in macroalgae. J Chromatogr A. 2002; 976(1-2):277-84. doi: 10.1016/s0021-9673(02)00934-2.

Slavin JL, Lloyd B. Health benefits of fruits and vegetables. Adv Nutr. 2012;3(4):506-16. doi: 10.3945/an.112.002154.

Slinkard K, Singleton VL. Total phenol analysis-automation and comparison with manual methods. Am. J. Enol. Vitic. 1977; 28: 49-55.

Sun L, Zhang J, Lu X, Zhang L, Zhang Y. Evaluation to the antioxidant activity of total flavonoids extract from persimmon (Diospyros kaki L.) leaves. Food Chem Toxicol. 2011; 49(10):2689-96. doi: 10.1016/j.fct.2011.07.042.

Woo Y, Lee H, Jeong YS, Shin GY, Oh JG, Kim JS, Oh J. Antioxidant potential of selected Korean edible plant extracts. Biomed Res Int. 2017; 2017: 7695605. doi: 10.1155/2017/7695605.

$\mathrm{Zu} \mathrm{Y,} \mathrm{Li} \mathrm{C,} \mathrm{Fu} \mathrm{Y,} \mathrm{Zhao} \mathrm{C.} \mathrm{Simultaneous} \mathrm{determination} \mathrm{of}$ catechin, rutin, quercetin kaempferol and isorhamnetin in the extract of sea buckthorn (Hippophae rhamnoides L.) leaves by RP-HPLC with DAD. J Pharm Biomed Anal. 2006; 41(3):714-9. doi: 10.1016/j.jpba.2005.04.052. 